\title{
Children Working in the Informal Sector: A Case Study of Child Workers at Istiqlal Mosque Jakarta
}

\author{
Arif Syaripudin \\ Master Candidate in Social Anthropology, Universitas Indonesia \\ LPDP RI
}

\begin{abstract}
This paper is related to the issue of child workers involved in some types of informal work in urban areas. Responding to the reality of children who spend their time on work or commonly called "child worker", is still seen as one of the marginalized parties. Children are often referred to the passive and unvoiced category of human beings, and sometimes their presence in society has never been involved in certain value production actions, such as work. This paper is an anthropological thinking on child workers which specifically contains the emic perspectives of children. In this fieldwork, I chose a social setting where some groups of children and their families do some informal work around Istiqlal Mosque Jakarta. Based on investigations through the participation-observations, guided deep-interviews, and interactive communication with child workers on several occasions, some important examining factors are provided the presenting children' contribution to their informal sector's work. In fact, factors that trigger their work contribution belong to as manifestation of autonomy and initiative, social, cultural, and economic motivation are also explained as a response to the challenging situation that they must be encountered. In addition, this study offers insights into various constructive meanings about the informal work chosen by children based on their own thoughts and experiences over the certain work situation.
\end{abstract}

Keywords: child workers, child contribution, informal sector, determinant factors.

\section{Introduction}

The discourse on child worker was initially grown and emerged from the European land, especially when it is attached to the work activities of children during the industrialization period in capitalist system's framework (Nieuwenhuys, 1996: 238). The existence of child worker in the informal sector, in my opinion, has become one of the social phenomena that have recently been discussed much because the issue is seen as something that exists with distinctive attributes attached to it. Statement listed in the ILO Convention 1999 on the issue of child worker acknowledged that, "the emergence of child worker is a social problem that arises for social poverty reasons, in which long-term solutions to address them is done through the efforts of economic growth by the multiple parties that lead to a social development such as children's welfare and education in any form". Moreover, the discourse on child worker has developed in the context of countries that are economically emerging. There are often morality judgments popped out which considers that the existence of child worker is a condition of underdevelopment country due to the absence of the state as a party that should protect children from anything that could harm their physical, psychological, and social condition (Anker, 2001: 86).

Definition of a child as stated in the Convention on Rights of the Children of 1990 by the United Nations and Indonesia law No. 23 of 2002 defined as every human being below the age of eighteen, including children who are still inside the womb. Based on ILO Convention 1999 No. 138 in Geneva stated that the minimum age for employment is 14 years for some types of work on condition that the nation gives permission for workers in that age and still provide some protection of both physical and psychological, safety and morality, as well as child workers must be guaranteed with a given vocational skills trained by those who employ them.

The debate of considering the thoughts of children initially came up with the assumption that children are often referred to as a passive and unvoiced party, and its presence in modern society has never been involved in 
the production of value. In addition, there is a certain pretension where adults did not pay attention (irrespective) to what children do as well as what they think of their actions. The above assumptions regarded as forgetting to certain capacity owned in every child. Only after that, the counter-discourse thought appeared and argued that the children also have their social agency to indicate the capacity in him/her to be realized in various ways either thought or action, "one basic right of every child is how he/she builds his/her capacity and his/her own views, the right to express their views freely in all matters affecting the child, and the child's view given on the basis of his/her interests/needs, age and maturity of the child" (CRC, UN 1990, Article 12 Paragraph 1).The statement, substantially, explained that these child workers can not be said to be a group that is lower than the other social groups that are considered more established/dominant in term of social stratification. It also contains a logic system of the children as actors who should receive recognition and it should be understood that this group has the capacity for developing creativity, being independent in various ways, and so on.

This paper will bring an understanding of the reality of what happened in urban societies' life, and one of the interesting issues could be child worker in the informal sector. I myself will focus on learning about the child workers' daily life through the framework of cultural relativism to show their various social-cultural normalities that naturally emerged to the work they have done. My major effort for an understanding of child labor issues can be obtained from how I look reality in the community through the local people's point of view directed to child worker's considerations. In addition, I am interested in knowing about how these working children from social agency's perspective relating to their social role in doing some informal jobs. It can be studied from the reasons and motivations they describe; And how children can work with the type of work they choose, and how children interpret their work based on their thoughts and experiences.

\section{Background and Research Setting}

The issue of change often associated with the concept of globalization. In the notion of socio-cultural change, it occurs as a result of an active process that involves some apparatus such as the development of information technology and communication, as well as the current mobility intensified, so the process will have impacts on the social and cultural problems (Kottak, 2011: 43). The manifestation of that its active process, for example, the expansion of the market is increasingly ruling against the social system and provides a real impact on the community. In urban communities, the integration of global market had an impact on the labor market's competition.

In some third world countries, there has an adjustment process in the field of socio-economic life, such as getting noticed informal sector as an option in economic activities. The informal sector is becoming part of the economic system in some developing countries like in Indonesia. The informal sector is also conceived as a domain that is able to absorb the job for most people. Those working in this field generally perform socioeconomic activities such as small traders (hawkers), services (repair, brokers, laundry workers), industries (food, furniture), transportations (public transportation, motorcycles, rickshaws) and construction workers (masons, carpenters) (Daldjoeni, 1985: 35). From 3 billion the number of workers around the world, as much as 2/3 of them work in the informal sector (Porto et al, 2016: 143).

Responding to the reality of children who spend their activities to work with the orientation of obtaining income therefrom, or so-called "child workers", has been a concern shared between several parties, such as the state, NGOs, and others. Based on the latest statistical survey in 2015, the Ministry of Labor (Kemenaker) Republic of Indonesia released the information about the trend of child worker aged 15-17 years old worker continued to increase to 1.65 million people. There is only part of the total number of child workers in Indonesia because out there is still a lot of under 15-17 years old child worker who was also involved in the informal sector.

In Indonesia itself, the existence of child worker is still regarded as one of the parties being marginalized.Various assumptions mentioned that the appearance child workers in the informal sector generally come from lower-class communities. They are born and socialized in a family entangled in a web of poverty (poverty trap). Those people who are in the bondage of poverty considered the world out there is a challenging 
arena, trying to work hard to achieve the job to fulfill their life's necessities and to free themselves from poverty (Chambers, 1987). Remembering the conditions of family's poverty used as one indicator that encourages the presence of child labor in urban areas, so the investigation into the background and segmentation of socioeconomic conditions or social class is important. Differences in layers of social class and status helped determine the differentiation in income, interest, and capacity to carry out economic resources (Carrier and Heyman, 1997: 363). Plunging children into informal work in some communities is considered as a process of socialization for children. The socialization process can be understood as a process of cultural learning within the social system in which an individual can learn about the patterns of action through interaction with other individuals around him/her with a variety of social roles that may be present in everyday life (Koentjaraningrat 1981: 229). Thus, placing children in a work was marked as the phase of child's learning about a social role in different ways and actions, then he can adjust to and interact socially with the work environment so that eventually evolved into a cultural pattern.

The social setting I chose in this research is that the children whose work in the informal sector at Istiqlal mosque Jakarta. Child worker in urban areas is considered as a manifestation of social complexity. If we reflect on intersectionalism approach, in fact, that it involves some factors that are interrelated with one another. Therefore, I mean that the signification in my paper is that to expose the child's capabilities like in the notion of social agency and talents and also to understand children' perspective in explaining their own view of their unique world and life. In addition, this research also provides my reflection as it takes from empirical observation of child workers' problem and its complexity based on social facts present in the social setting.

\section{Research Methodology}

In this research, I did a single-sited ethnography, then as an entry point, I used Istiqlal mosque to be my space orientation. To gain access and link to child worker, I tried to approach them through a gatekeeper who in everyday life involved with the children, their workplace and of course he has a good relationship with them and their parents. However, child laborers studied in this research are those with 12-18 years group of age as it means children who are still at primary school and junior high school ages.

How ethnographic research has been done by me is to perform an immersion through participant observation and interactive communication with interviewing the informants. The researcher must undertake a process of immersion, immerse himself/herself by taking part in a celebration of the social events and social process (Wax and Wax, 1980: 29-30). I would go in and "step into" some working children as my research subjects. Besides that, I had also interacted with some significant informants such as his/her parents, adult workers, and Istiqlal security guards to gain some information as emic statements. The anthropologist should be able to explain the world of meaning and moral system of society in which he lives and engage with them (Emmerson, et.al., 1995: 11). The efforts towards the understanding of how researchers can be obtained social-cultural meanings because they are learning about community's lives through emic perspectives (Saukko, 2003: 57). Furthermore, matters relating to listen emic perspective, it can also be focused on the empirical logics and sensitivities which had become into something that is significant, meaningful, tangible, feasible and accurate as performed by the actor (Harris, 1968: 571). Several times I also used friends of friend methodology which allows me to know the other child workers through a relationship or friendship connection of child worker itself to be able to get information from the other child workers. To obtain secondary data, I took the information through a library research (library research method), which is a research technique that is done by studying books/literature, documents, or other papers. I design this research to be a descriptive essay. Furthermore, data will be obtained with a qualitative approach which is an exploration. 


\section{Child Worker in the Informal Sector at Masjid Istiqlal}

When we talk about the concept of informal work, of course, we can not resist but we may require an understanding of what the formal work means. Formal employment is often considered as a basic or standard, well-established, normative work. While informal employment is a domain that is explained to a work possess a loose and flexibility in hours and its workplace, allowing individuals to get involved and express their freedom in choosing how to work with all the capabilities of them (Rolis, 2013: 93). In many studies, this informal sector in developing countries could become a shelter that will save up to 70 percent of the job. In Indonesia, the informal sector involved in the community can be in trade activity, especially a petty trade. Petty trade sector is very easily accessible by anyone because there is no specific requirement (such as education, specific skills, or capital) which must be needed (Gandarsih, 1994: 8).

The thing I realized from my observations in the field, those working children did not work alone, but there are other children at relatively same age doing the same profession as child labor. On several occasions I came to them, I found that the existence of child labor tends to live and work together with other children. Furthermore, I tried to approach and observe when they were getting involved in one group. As it turned out, within a group there are activities showed that social relations among them are sticking up for each other. Children working at the Istiqlal mosque usually perform their job in the scope of space that can still be reached and observed by their parents. For them, Istiqlal mosque is a location that would be used to sustain the economic life to attain family's daily needs. It convinced me that Istiqlal mosque and its vicinity is a locus for them to fight their economic life through working in the informal sectors.

However, the existence of these child workers generally come from a marginalized social group with vulnerable economic position and capacity. This marginal group can be considered to be the people who still adjusting to the uncertain situation by constructing some realistic strategies with all specific capabilities they have in life. Because of social pressure, child worker emerged to be an actor who needs encouragement to adapt to such challenging circumstances. In the end, informal work has to become something chosen and accepted by child workers and their families.

\section{Social Determinant: Child Worker's Family Backgrounds}

To determine differences in the social background in the community, we can simply see the smallest unit of organization in the society, such as the notion of family. Family is the smallest social institution in the social system where individuals living together with their own characteristics and social dynamics (Martono, 2011: 233). Social determinant of a child worker in Istiqlal mosque as I know that they come from vulnerable's social group. "Vulnerable" here is meant that some child workers I have met, they lived and grew up in a lower class family which their household's conditions, in fact, have a little bit economic buffer to deal with everyday needs. People came from lower class society, they thought themselves as vulnerable families trapped in a condition because of economic inequality, for example in terms of differentiation of daily earnings (Martono, 2014: 163).One way to support the economic situation is to do that informal work looking for some income's source. Income can be considered as part of their main achievements and it is the thing very helpful for their life (Schor and Holt, 2000: 213).

Given issues of family, there are also some child workers who came from a single-parent family, it may be due to divorced, separated, widowed, or perhaps never married, and their children live with one of the parents, "I am a second son, mas (mas: Indonesian' greeting name). My oldest brother, a man who works the same as I am, an informal seller. My father had died since the time I was two years old. So, we lived now together with my mom at home " (Daniel, 13 years old, Child Worker). In addition to the case of bereaved parents, another significant information about other child workers' family situations which I successfully traced is that there are some children who grew up working in the cracked family circumstances or broken family. It happened to Farel, 13 years old's child worker. He himself comes from a family where his parents divorced when he was a little boy. Currently, he is living with his mother and stepfather and has a half-sister from his mother's second 
marriage. Of the reality described above, we can explain that the meaning of a social condition is so relative. One determinant can go through the social condition and social relation that built in a family. So, when relating to the meaning of a child worker's family background that could be correlated with a value/condition that describes some characteristics such as socio-economic circumstances that relatively weak, the type of work, as well as the conditions of a cracked family unit.

\section{Kids For Family's Worker : A Motivation}

Responding to the reality of child worker in the informal sector, children actually have helped carry out economic functions with the intention of establishing an economic cooperation for family income. The involvement of children in work helping their family certainly had constructed the concept of a family worker. With this family worker, it is also a common phenomenon that parents are using worker force of the family members-including children- to earn immediate income from work (Usman and Nachrowi, 2004: 47).In a family, each person occupies their own position so that the organization can have a social function. The family also can work together in performing economic functions related to production, consumption, and distribution in an effort to fulfill the needs (Saifuddin, 1999: 21). Another thing indicated to the conception of the child as a family worker is because of social motivation for encouraging economic necessity. To explain why a child is engaged in informal work as well as social motivation itself. Understanding of its social motivation can be described as an impulse arising on a person to commit an act with a specific purpose (Geertz, 1973: 97). "I want to keep this selling activity to continue to help my mother. I do not want to go back to school until now. It's my right to help my mom merchandising. My mother also sells coffee, same as mine. But, we took a different place. Money from this incomes were all given to my mom for everyday purposes as well as a capital to buy materials for the next day's trading. I do not expect a wage from it because this work has to be devotion to my parent (Daniel, 2017). Therefore, the phenomenon of child worker here was born as a manifestation of child's motivation to work as a process that occurs within him to construct meaning of the internal conditions in the family. Internal factors here, for example, the weak social economic background, an absence of the headman's role of household, uncertainty in income level and type of job, and so on. It said that, in other instances, relate to the understanding of what social agency is, this means that there is about an embodiment of social autonomy, and the expression of one's capacity in which he/she has his own initiative and creativity in responding to the situation (Mahmood, 2005: 6; Gidden, 1984 in Jones, 2016: 243). In addition, the role of children as family workers indicate that in this case, the child becomes part of economic functions. Finally, a child worker in the family can work as a social mechanism to help accomplishing family needs.

\section{Child Worker and Cultural Factor}

Another factor such as the construction of cultural values in the community also brings children to the domain of work. In some of the family I learned, there is still a perception that by engaging children in work is a way of parents in educating children personality because it allows themselves to be an independent person instilled in early age. It was also supported by the thought that because of it, children can get to know what the real world of work is when they become an adult. According to my informant, informal workers including children used to start the daily work activities approximately from $03.30 \mathrm{pm}$, since the mosque main gate is opened, until $22.00 \mathrm{pm}$. "It means that the activity is relatively long, sir?" I asked. Then, with smiling, he replied, "Yes, it's our habit when we are here, and I train my kids to this activity so that they will be familiar with". Seeing that statement, personality development in a person can be described from how intensely a child is dealing with the process of socialization from parents in so many particular roles in the household or family, as well as when entering adult age, they will be used to perform that social role. 


\section{Day-to-Day Challenges of Child Workers}

After explaining how the positive influence from work activity doing by children, there is an important thing for me to also see that the work done by children in everyday life is faced with some challenges both at their work and social development. In this discussion, I will first review of how the child workers have some challenges regarded to their basic education. Because children involved in adult activities such as working, then it could allow declining their achievement in school, and some of them, unfortunately, had dropped out of school. Based on my informants' experience, the brother-sister child workers ( $\mathrm{H}$ and $\mathrm{A}$ ) have also the same issue due to their education program. H must be stopped in the third grade of primary school, while her sister A is not at all to get a formal education yet. A similar story experienced by Daniel, when his father had died since he turned two years old, Daniel was forced to quit school after graduating from sixth grade. The reasons why he decided for dropping out of school are based on Daniel himself who realized that he should follow his nomadic mom. His mom often migrates from one place to another to just work. He was forced to join her parents. He wants to keep its activity continuing to help his mother trading, "I do not want to go back to school until now. I still kept selling to help my parents", he said.

Beside children's education issues, other challenges that arise, children are being forced into an economic exploitation by adults which can inhibit their physical and psychological development, verbal abuse, even a social judgement while they working with adult workers, also have to shield themselves against other parties such as mosque's security guards intersect in the field in which they work. For those who are victims of economic exploitation by their parents, for example, it occurs when child's bargaining position is in the very weak position. Thus, it was also driven by coercion and an excessive control of adults. Such kind of activity contained within the measures classified as physical and psychological violence. Like the case of $\mathrm{H}$ and $\mathrm{A}$, they, unfortunately, had been involved in child worker exploitation as became victims of their parents, "That brother and sister were working as forced by her parents. If they were not selling yet, they were instead forced to continue until they want to, and often their mother urged them with an angry face. Their mother did not work anything and in fact, their step-father is an unemployed man. Sometimes that poor little boy was working too hard, but the parents just take it easy and did nothing"(Mother Zae, Adult Worker, 2017). Based on informants' narratives above, the existence of child worker in some cases should be one of the thorny issues. And on the other hand, it brings an empathy feeling to some unfavorable conditions to them. In fact, they have no longer time to learn, play, or simply to rest because of repressive selling activity.

\section{Conclusion}

After finding the informants' narratives and experiences through a variety of research techniques, the results of this social research took me on several points' conclusions; Chances/opportunities as child worker in the informal sectors can be seen from the child's choice to follow and adapt realistically to such activities as one of the economic strategies to fulfill their basic needs in real everyday life, as well as improve the lives of families through earned income. Also, the condition when children are working, it does not necessarily rid itself into an economic exploitation because of adults' domination as well as its implications could lead to a condition in which children' physical and psychological development will be decreased. This research also explained that child workers based on my observations especially from their family background, in general, child workers are coming from low economic class and vulnerable families. Moreover, the role of parents also becomes one of the important determinants of why the child could then come into the informal employment domain. It was seen that some parents seem to allow their children to work as the way of educating children. In this case, child worker has been socialized on early age with the things that are considered to be part of adult activities, so that children will be someone better prepared when confronted with social conditions in the future. 


\section{Acknowledgments}

I express my deepest appreciation and thanks to the Istiqlal authority officer and my beloved informants for their kindness and support as well as always being of good individuals in delivering their thoughtful comments, stories, and experiences during I conducted this social research until it had finally finished. I also thank LPDP (Indonesia Endowment Fund for Education) from Ministry of Finance of the Republic of Indonesia as a funding institution that has helped make possible this research to be presented at the 10th International Conference on Languages, Humanities, Education and Social Sciences (LHESS-18) held on April 19-20, 2018 in Kyoto, Japan. I do hope this research will enrich our understanding from many things, especially in learning the diversity of humankind and its complexities, so that we can learn from them and inspire other social researcher to have the same interest in working fieldwork with child worker issues.

\section{References}

[1] Anker, Richard, Child labors and Its Elimination: Actors and Institutions, Amsterdam: Aksant Publisher, 2001, pp. 86.

[2] Cassel, Juan, "Ethical Principles for Conducting Fieldwork", American Anthropologist (NS), 1980, vol. 82, no. 1, pp. $28-41$.

https://doi.org/10.1525/aa.1980.82.1.02a00020

[3] Carrier, James G and Josiah Mc. Heyman, "Consumption and Political Economy", The Journal of the Royal Anthropological Institute, 1997, vol. 2, no.1, pp. 355-373.

[4] Djaldjoeni, N, Seluk Beluk Masyarakat Kota, Bandung: Publisher Alumni, 1985, pp. 35.

[5] Chamber, Robert, Rural Development: From Rear, Jakarta: LP3ES, 1987.

[6] Emmerson, RM, et al., Ethnographic Writing Fieldnotes, Chicago: The University of Chicago Press, 1995. Pp. 11. https://doi.org/10.7208/chicago/9780226206851.001.0001

[7] Geertz, Clifford, Interpretation of Culture, Yogyakarta: Canisius, 1973.

[8] Hierschfeld, Lawrence, "Why Do not Anthropologidt Like Children", American Anthropologist, 2003, vol. 104, vol. 2, pp. 611-627.

[9] Indonesia Law on Child Protection, 2002, no. 23, article 10.

[10] Jones, Pip et. al., Pengantar Teori-Teori Sosial (Indonesian Translation), Jakarta : Yayasan Obor Indonesia, 2016, pp.243.

[11] Koentjaraningrat, Pengantar Ilmu Antropologi, Jakarta : Rineka Cipta, 1990, pp.229.

[12] Kottak, Conrad Phillip, Cultural Anthropology: Cultural Diversity appreciating [14th Edition], New York: McGrawHill, 2011.

[13] Marcus, George, "Ethnography in / of the World System: The Emergence of Multi-Sited Ethnography", Annual Review of Anthropology, 1995, vol. 24, pp. 95-117.

https://doi.org/10.1146/annurev.an.24.100195.000523

[14] Mahmood, Saba, The Islamic Revival and the Feminist Subject, Princeton: Princeton University Press, 2005, pp. 6.

[15] Nieuwenhuys, Olga, "The Paradox of Child Labor and Anthropology", Annual Review of Anthropology, 1996, vol. 25, pp. 237-251.

https://doi.org/10.1146/annurev.anthro.25.1.237

[16] Porto, Eduardo et al, "Informal Work in a Flexible Labor Market", Oxford Economic Paper, 2016, vol. 69, pp. 143-164. https://doi.org/10.1093/oep/gpw010

[17] Saifuddin, AF, "Families and Households: Unit of Research in Community Change", Indonesia Journal of Anthropology, 1999, vol.50, pp. 19-24 
[18] Schor, Juliet B. and Douglas B. Holt, The Consumer Society Reader. New York: The New Press, 2000, pp. 213.

[19] Usman, Hardius and Nachrowi, NJ, Child Labor in Indonesia, Jakarta: Gramedia, 2004, pp.47.

[20] United Nations, Convention on the Rights of Children, 1990, article 12, paragraph 1.

[21] Wax, ML and RH Wax, "Fieldwork and Research Process", Anthropology and Education Quarterly Anthropology and Education, 1980, vol.11, no.1, pp. 29-37.

https://doi.org/10.1525/aeq.1980.11.1.05x1848b 